\title{
Proposed Changes in Federal Taxation of Community Property: Income Tax*
}

\author{
George E. Rayi
}

For more than twenty years the community property system has

been used to effect reductions in the federal income tax liabilities of the residents of eight states of the Union. ${ }^{1}$ The division by a husband and wife residing in one of those states of their earned income and income derived from community propery has enabled them to take advantage of the graduated surtax rates with a lower tax for the family as a unit than would result in the case of a family similarly circumstanced in any of the forty non-community property states. ${ }^{2}$ Numerous unsuccessful efforts to remove this tax advantage have been made by the Treasury through resort to judicial and legislative means.

The attack in the courts was based on the contention that in community property states the income of the community was the income of the spouse having management and control of the income, that spouse being the husband. The Supreme Court rejected this argument on the ground that to tax one person upon the income of another would violate the due process clause of the Fifth Amendment. ${ }^{3}$ The attack in Congress was made along two different lines. The first, directed exclusively against community property, represented an effort to tax income of the community to the spouse having manageinent and control of such income, ${ }^{4}$ with later refinements to tax

*This article will appear in two parts. The second will deal with estate and gift taxation and will be published in the July 1942 issue of this Review.

$\dagger$ Member of the Massachusetts and New York Bars; A.B. 1932, LL.B. 1935, Harvard University. Author of The Income Tax on Short-Term antd Revocable Trusts (1940) 53 HARv. L. REv. 1322; and The Estate Tax on Transfers Intended to Take Effect in Possession or Enjoyment At or After Death: Helvering v. Hallock (1941) 29 GEo. L. J. 943.

1 Those states are Arizona, California, Idaho, Louisiana, Nevada, New Mexico, Texas, and Washington. The efforts of Califormians were frustrated until the state legislature came to the rescue in 1927 . Okjahoma increased the group to nine states when it adopted colnununity property in 1939 .

2 See Griswold, Letter to the New York Times, Jan. 12, 1941, at 8E, cols. 5, 6.

3 Poe v. Seaborn (1930) 282 U. S. 101.

4 Such attempts were made in connection with the Revenue Acts of 1921, 1924, 1934, and 1941. On the 1921 proposal, contained in section 208 of the bill as passed by the House, see H. R. REP. No. 350, 67th Cong. 1st Sess. (1921) Ser. No. 7921, at 1; (1921) 61 Cong. Rec. 5909, 5922, 7229 ; H. R. Rep. No. 486, Amend. No. 134, 67th Cong. 
earned income of the community to the earner. ${ }^{5}$ The second, in the form of mandatory joint returns, ${ }^{6}$ was intended to tax the income of a husband and wife in every state as a unit, thereby removing the advantage that comes in all states from being able to divide the family income for tax purposes, either by having both spouses earn income or by transfers of income-producing property from one spouse to the other. ${ }^{7}$

Community property presents a problem under the estate and gift taxes also, since upon the death of a husband or wife in a cominunity property state one-half of the cominunity property is included in his or her estate, and where a gift of community property is made the gift is taxed one-half to each spouse. Although spouses in non-community property states may similarly reduce their estate and gift tax liabilities by holding property as tenants in common, or as the separate property of each spouse, they must first meet the gift tax barrier at the time of the transfer from one spouse to the other. In the estate and gift tax fields the Treasury has been content to

1st Sess. (1921) Ser. No. 7921, at 21. On the 1924 so-called "Mellon plan", see (1925) 67 Cong. Rec. 175, 176; Hearings Before Comomttee on Ways and Means, Revenue Revision 1924, 68th Cong. 1st Sess. (1924) at 348, 349, 375, 478, 482. On the 1934 "Treadway Bill", H. R. 8396, 73d Cong. 2d Sess., see Prectaminary Report of a Subcomartite of tee Compattiee on Waxs and Means Rejative to Methods of Preventino the

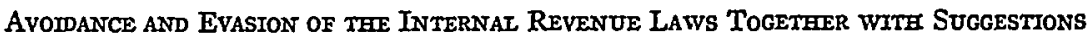
FOR tEe Starplification and IMrprovement Thereof, H. R. Rep. No. 704, pt. 2, 73d Cong. 2d Sess. (1934) Ser. No. 9775, at 9. The 1941 provision was contained in section 1 ì of H. R. 5417 (Revenue Act of 1941) as reported by the Finance Committee of the Senate in SEN. REP. No. 673, 77th Cong. 1st Sess. (1941) at 32.

- Ibid.

6 Proposals for mandatory joint returns were made in 1934, 1937, and 1941. HEARINGS, Revenue Revision 1934, H. R. Rep. No. 704, pt. 2, 73d Cong. 2d Sess. (1934) Ser. No. 9775, at 113; HeArINGS Before tHe JoInt Comomtriee on TaX Evasion aNd Avordarce, pt. 2, 75th Cong. 1st Sess. (1937) at 310; H. R. REp. No. 1040 oN H. R. 5417, 77th Cong. 1st Sess. (1941) at 13, $\$ 111$ (Revenue Act of 1941) as reported by the Committee on Ways and Means.

7 The advantage made possihle by the privilege of husbands and wives to file separate returns or joint returns at their own option operates against the great bulk of taxpayers and in favor of a small group. Of the 3,041,624 married couples filing income tax returns on income for the calendar year $1938,2,866,026$ or 94.3 percent, voluntarily filed joint returns and 175,598 , or 5.7 percent, elected to file separate returns. $H$. R. REP. No. 1040 on H. R. 5417, op. cit. supra note 6, at 17. That only a few persons in the community property states derive tax benefits out of the community property system is evidenced by the fact that only 4.78 percent of the returns filed in commumity property states in 1938 were community property returns. It is further evident that those filing community property returns are not those with low incomes, since the net income shown on such returns constituted 18.5 percent of the total net income on all returns in the community property states in that year. SEN. REP. No. 673, pt. 1, op. cit. supra note 4, at 10. 
follow the result reached under the income tax and has as yet made no effort to obtain remedial legislation.

In the community property states, the property of a husband and wife is divided into (1) the separate property of the husband, (2) the separate property of the wife, and (3) community property. ${ }^{8}$ All property acquired during marriage by the industry and labor of either the husband or the wife, or both, together with the produce and increase thereof, generally belongs beneficially to both during the continuance of the marital relationship. ${ }^{9}$ All acquisitions of either spouse, other than those arising by gift, devise, or descent, belong to the community. ${ }^{10}$ The husband is the head and master of the community. ${ }^{11}$ As such, he has the general management and control of all the property of the community ${ }^{12}$ whether personal or real and whether standing in his name or that of his wife. In the exercise of his powers, he may contract community debts, and, subject to limitations in some jurisdictions respecting the necessity of the wife's consent or jomder, or good faith toward her, he may dispose of the community property by sale or even by gift. ${ }^{13}$ He may likewise mortgage or otherwise encumber it. He is not accountable for any use or disposition which he may make of community property, short of fraud or violation of specific limitations upon his power of control. ${ }^{14}$ Conversely, except where her consent is necessary to disposition of community property, the wife generally has no power of control or management, and she cannot without his consent make any valid contract with reference to the property and cannot dispose of the same either by gift or sale; nor can she mortgage or otherwise encumber it, or contract community debts. ${ }^{15}$ She can, however, except

${ }^{8}$ La Tourette v. La Tourette (1914) 15 Ariz. 200, 137 Pac. 426; Hall v. Johns (1909) 17 Idaho 224, 105 Pac. 71.

${ }^{9}$ Winchester v. Winchester (1917) 175 Cal. 391, 165 Pac. 965 ; La Tourette v. Ia Tourelte, supra note 8.

10 Garver v. Thoman (1913) 15 Ariz. 38, 135 Pac. 724.

11 See Garrozi v. Dastas (1907) 204 U. S. 64, 81.

12 See Arnett v. Reade (1911) 220 U. S. 311, 319; McKay, Conarunity Property (2d ed. 1925) §672.

13 See Evans, The Ownership of Community Property (1921) 35 Harv. L. Rev. 47,64 .

14 See United States v. Robbins (1926) 269 U. S. 315, 327; Poe v. Seaborn, supra note 3 , at 110 .

15 See Daggett, The Modern Problem of the Nature of the Wife's Interest in Community Property-A Comprehensive Study (1931) 19 CALIF. L. REv. 567, 601; Hooker, Nature of Wife's Interest in Community Property in California (1927) 15 Carre. L. REv. 302, 312. 
in Nevada, dispose of one-half by will. The husband's right to control and manage community property does not depend upon delivery of the property to him, and is not impaired by possession of the wife. Enforcement and protection of community rights generally fall to him as the head and manager of the community..$^{10}$

The origin of the system is not clear, although it appears to have first arisen with some of the Teutonic people. ${ }^{17}$ In California, Louisiana, New Mexico, and Texas the system was obtained directly from the Spanish and Mexican law. ${ }^{18}$ Commumity property was adopted by statute in Arizona and Nevada in $1865,{ }^{19} \mathrm{~m}$ Washington in $1869,{ }^{20}$ in Idaho in $1875^{21}$ and in Oklahoma on July 29, 1939.22 The system also prevails in Puerto Rico, ${ }^{23}$ the Philippine Islands, ${ }^{24}$ Mexico, ${ }^{25}$ the Province of Quebec, ${ }^{28}$ Spain $^{2 \pi}$ and France. ${ }^{28}$

DIFFERENCES BETWEEN THE INCIDENCE OF FEDERAL INCOME TAX-

ATION IN COMMUNITY PROPERTY STATES AND IN OTHER STATES

Earned Income-In non-community property states earned income is generally taxable to the earner. In Lucas v. Earl ${ }^{29}$ the Supreme Court held that an assignment of future income by a husband to his wife would not relieve him of tax on the income, stating, ${ }^{80}$

"There is no doubt that the statute could tax salaries to those who earned them and provide that the tax could not be escaped by antici-

16 I PaUt, Federat Estate and Gift Taxation (1942) \$1.09; 3 Vernier, American Fanmor Laws (1935) 218, 221; Sebree, Federal Taxation of Community Property (1934) 12 Tex. L. REv. 273, 275-281.

17 McKaY, op. cit. supra note 12, §§ 7-9; see Cole's Widow v. His Executors (La. 1828) 7 Mart. (N.S.) 41, 18 Am. Dec. 241.

18 Spreckels v. Spreckels (1897) 116 Cal. 339, 48 Pac. 228; Saul v. His Creditors (La. 1928) 5 Mart. (N. S.) 569, 16 Am. Dec. 212; Beals v. Ares (1919) 25 N. M. 459, 185 Pac. 780.

19 Stiles v. Lord (1886) 2 Ariz. 154, 11 Pac. 314; Lake v. Bender (1884) 18 Nev. 361, 4 Pac. 711.

20 WASH. REv. STAT. (Remington, 1932) § 6890.

21 Idaho Rev. Laws 1875, p. 634; Jacobson v. Bunker Hill etc. Co. (1891) 3 Idaho 126, 28 Pac. 396.

22 Okla. Laws 1939, c. 62 , art. $2, \$ 1$.

23 Garzot v. DeRubio (1908) 209 U. S. 283.

24 Madrigal v. Rafferty (1918) 38 Philippine 414.

25 In re Buchanan's Estate (1857) 8 Cal. 507.

26 Bastien v. Filiatrault (1900) 31 Can. Sup. Ct. 129.

27 Meyer v. Kinzer and Wife (1859) 12 Cal. 248.

28 Richardson v. De Giverville (1891) 107 Mo. 422, 17 S. W. 974.

29 (1930) 281 U.S. 111.

$80 \mathrm{Ibid}$. at 114 . 
patory arrangements and contracts however skilfully devised to prevent the salary when paid from vesting even for a second in the man who earned it." 31

It has recently been held by the Supreme Court that where the income assigned is received as compensation for services rendered in the past by the assignor.he is taxable thereon. ${ }^{32}$.

In the community property states, earned income of the spouses generally becomes community property and may be divided by the spouses in equal portions for federal income tax purposes ${ }^{33}$ Not until its decision in United States v. Malcolm, was it held by the Supreme Court that the wife in California has a vested interest in community property, and then, by virtue of an aniendment to the Civil Code of that state, only as to property acquired after July 29, 1927.34 The Bureau of Internal Revenue has taken the position that the Oklahoma community property law, ${ }^{35}$ pernitting residents of Oklahoma to hold in community any property acquired after the filing of a written election, does not warrant the division by a husband and wife of the husband's salary for federal inconie tax purposes. ${ }^{36}$

While in non-community property states the earned income credit provided in section 25 of the Internal Revenue Code can be claimed only by the person earning the income, in community property states the credit arising with respect to earned income constituting community property may be divided between the two spouses when they make separate returns. ${ }^{37}$ In some community property states a husband and wife inay enter into an agreement whereby the earnings of

31 Cf. Burnet v. Leininger (1932) 285 U. S. 136.

32 Helvering v. Eubank (1940) 311 U. S. 122. Cf. Helvering v. Horst (1940) 311 U. S. 112; Harrison v. Schaffner (1941) 312 U. S. 579. Earlier cases to the contrary rested on the ground that the assignment was that of a property interest rather than of income. Hall v. Burnet (App. D. C. 1931) 54 F. (2d) 443; George O. Knapp (1939) 40 B. T. A. 1145. Cf. Blair v. Commissioner (1937) 300 U. S. 5.

33 Poe v. Seaborn, supra note 3 (Washington); Goodell v. Koch (1930) 282 U.S. 118 (Arizona) ; Hopkins v. Bacon (1930) 282 U.S. 122 (Texas); Bender v. Pfaff (1930) 282 U. S. 127 (Louisiana); United States v. Malcolm (1931) 282 U. S. 792 (California, as to salaries, wages, or fees earned after July 29, 1927). Following the first four of these Supreme Court decisions, the same rule was promulgated by the Treasury Department for Idaho, Nevada, and New Mexico. Mim. 3853, X-1 C. B. 139.

34 Supra note 33; CaI. Crv. Code \$161a.

35 Okla. Laws 1939 , c. 62 , art. $2, \S 1$.

36 Petitions and answers have been filed with the Board of Tax Appeals on this point in the following cases: J. A. LaFortune, No. 107160; Thomas A. Creekmore, No. 107189 ; J. Wood Glass, No. 108311 ; John Curran, No. 108445.

37 U. S. Treas. Reg. 103 (1940, amend. 1941) § 19.25-2; Graham v. Commissioner (C. C. A. 9th, 1938) 95 F. (2d) 174. But cf. Mrs. Frank Andrews (1932) 26 B. T. A. 642. 
each spouse are to be the separate property of the earner and thereby make the earnings of each spouse taxable as separate property.98 This is also true as to the income from community property, ${ }^{30}$ but the rule is otherwise in New Mexico and Texas. ${ }^{10}$

Residents of countries having a community property system who earn income within the United States and citizens of the United States who reside and earn income in such countries, like the residents of community property states, are able to divide their earned income for federal income tax purposes. Residents of Switzerland, where the community property system exists, may divide between the spouses mcome earned within the United States. ${ }^{41}$ Citizens of the United States residing in Mexico, ${ }^{42}$ France, ${ }^{43}$ and, in certain instances, in the Philippine Islands, ${ }^{44}$ may divide earned income between the spouses. The Treasury has ruled, however, that United States citizens residing im Cuba, ${ }^{45}$ the Virgin Islands, ${ }^{46}$ and Spain, ${ }^{4 \pi}$ may not divide their earned income, since in those jurisdictions the wife's interest in the community property is not vested.

Income from Property. - In the non-community property states, income derived froin property is generally taxed to the owner of the property. The liability for tax is not relieved by a transfer of the ownership, if control or substantial benefits of ownership are retained by the transferor. ${ }^{48}$ The income from estates by the entirety and from property held as joint tenants by a husband and wife may generally be reported one-half by each spouse. ${ }^{48}$ In states such as Michigan, Maryland, Missouri, New York, and Florida, where the wife has control of the income from her property, this produces a result similar to that which obtains in community property states with respect to community property. ${ }^{50}$ Under the common law, how-

38 Van Every v. Commissioner (C.C.A. 9th, 1940) 108 F. (2d) 650 (California). 30 Sparkman v. Commissioner (C. C. A. 9th, 1940) 112 F. (2d) 774.

4011 AMr. JUR. SUPP. \$ 62, n. 6.6.

41 G. C. M. 2892, VII-1 C. B. 158.

42 Juan F. Brittingham (1928) 13 B.T.A. 375.

43 I. T. 1414, I-2 C. B. 170.

14 I. T. 3173, 1938-1 C. B. 160; but cf. I. T. 1297, I-1 C. B. 235.

45 I. T. 1479, I-2 C. B. 172 ; cf. Sanchez v. Bowers (C. C. A. 2d, 1934) 70 F. (2d) 715.

46 I. T. 1763 , II-2 C. B. 180.

47 I. T. 1513 , I-2 C. B. 149.

48 I. R.C. $\$ \S 22(a), 166,167$. Burnet v. Wells (1933) 289 U. S. 670; Helvering v. Clifford (1940) 309 U. S. 331; Helvering v. Horst, supra note 32.

49 Commissioner v. Hart (C. C. A. 6th, 1935) 76 F. (2d) 864.

60 See 1 Montgomery, FederaI TAX HandBook, 1940-1941 (1940) 800. 
ever, the husband was entitled to the full use of an estate by the entirety and to the income therefrom during the existence of the marital relationship. Accordingly, in any state, such as Massachusetts, where the strict common-law conception of a tenancy by the entirety still exists, the income from such property is returnable only by the husband. ${ }^{51}$

In all the community property states, except Idaho, ${ }^{52}$ Louisiana $^{53}$ and Texas, ${ }^{54}$ income derived from the separate property of either spouse is taxable to the owner of such property or to the one having control or substantial benefits therefrom, as in non-commumity property states. ${ }^{55}$ In Idaho, Louisiana and Texas the income from separate property is itself community property. ${ }^{56}$ In Texas, by reason of a statutory change in $1929,{ }^{57}$ income from separate property, except the increase, rents and revenue from lands, during the existence of a marriage is held to be community property. ${ }^{58}$ But in that state capital gains, realized from the sale of the separate property of one of the spouses, constitute the separate income of that spouse..$^{50}$

In all the community property states income from commumity property may be divided between the spouses for federal income tax purposes. The right to divide income between the spouses depends upon the existence of the marriage. ${ }^{\circ 0}$ In a number of cases, taxpayers have been able to take advantage of the community property laws of states in which they did not reside. For example, in Hammonds v. Commissioner ${ }^{61}$ it was held that where spouses resided in Oklahoma, which was then a non-commumity property state, and the wife, in exchange for her personal services, acquired an interest in oil and gas leases situated in Texas, such leases were governed by the community property laws of that state and the gain on the sale of the leases was community income and divisible equally in the

61 Cooley v. Commissioner (C. C. A. 1st, 1935) 75 F. (2d) 188.

62 IDAHO CODE (1932) \& 31-907.

63 LA. CTv. CODE (Dart, 1932) § 2402.

64 Tex. Gen. \& Special Laws 1929, p. 66, § 1.

551 MonTgomerY, op. cit. supra note 50, at 813; cf. Guye v. Guye (1911) 63 Wash. 340, 115 Pac. 731.

56 McKax, op. cit. supra note $12, \S \S 283,284$.

67 Tex. Gen. \& Special Laws 1929, p. 66, § 1.

68 Commissioner v. Terry (C. C. A. 5th, 1934) 69 F. (2d) 969; cf. Arnold v. Leonard (1925) 114 Tex. 535, 273 S. W. 799.

59 O'Connor v. Commissioner (C. C. A. 5th, 1940) 110 F. (2d) 652.

60 Muriel Oakes Ames (1934) 30 B.T. A. 516.

61 (C. C. A. 10th, 1939) 106 F. (2d) 420. 
separate returns of the husband and wife. In Black v. Commissioner ${ }^{02}$ spouses resident in Oregon were held to own as community property an interest in lands in Washington and were therefore allowed to split their income for federal tax purposes, although the husband operated the land in partnership with his brother, and received the income through the partnership.

Husband and Wife Partnerships.-In non-community property states, wherever the state law permits partnerships between spouses, a husband and wife may divide business income between them by entering into a partnership, since under the federal income tax law ${ }^{03}$ individuals carrying on business in partnership are liable for income tax only in their mdividual capacity. ${ }^{64}$ In twenty-two non-community property states and the District of Columbia a husband and wife may enter into a partnership with each other, ${ }^{05}$ but in four states, however, Maine, Massachusetts, Michigan, and Vermont, a husband and wife are not empowered by state law to enter into a partnership agreement with each other. Even where partnerships may exist between husband and wife, however, unless each spouse contributes capital, labor or services, a bona fide partnership will be held not to exist. ${ }^{66}$

In community property states husbands and wives generally cannot enter into partnerships with each other, except insofar as the community property status may be considered to be a partnership. ${ }^{67}$ In California, however, the spouses may enter into a partnership, thereby changing their property from community to separate property ${ }^{68}$ Where a husband domiciled in a community property state is a member of a partnership, the Treasury permits the division between the husband and wife on their returns of such part of their distributive share of the partnership's capital gains and losses and

62 (C. C. A. 9th, 1940) 114 F. (2d) 355.

63 I. R. C. § 181.

64 Humphreys v. Commissioner (C. C.A.2d, 1937) 88 F. (2d) 430.

65 Alabama, Arkansas, Colorado, Connecticut, Florida, Georgia, Iowa, Kansas, Minnesota, Mississippi, Montana, Nebraska, New Jersey, New York, North Carolina, Ohio, Oregon, Pennsylvania, South Carolina, South Dakota, Virginia, and West Virginia. See 442 C. C. H. $\| 1169.21$. Commissioner v. Tenney (C. C. A. 1st, 1941) 120 F. (2d) 421.

66 Tinkhoff v. Commissioner (C. C. A. 7th, 1941) 120 F. (2d) 564; Robert S. Eaton (1938) 37 B.T. A. 283.

67 Board of Trade v. Hayden (1892) 4 Wash. 263, 30 Pac. 87.

$68 \mathrm{~J}$. Kammerdiner (1932) 25 B.T.A. 495. 
ordinary income and losses which is, or is derived from, community. property. ${ }^{\infty}$

Credits, Exemptions and Deductions. - In non-community property states credits, deductions and exemptions are generally not divisible between spouses. But taxes and interest paid in connection with property held by a husband and wife as tenants by the entirety have been ruled ${ }^{70}$ by the Treasury to be deductible by the spouse paying them. So also as to loss from hurricane. ${ }^{71}$

In the community property states the husband and wife may each claim the full amount of liberty bond exemption. ${ }^{72}$ It has been held that deductions properly chargeable against the income from community property should be equally divided. ${ }^{73}$ The Treasury holds that where dependent children are supported from community income, the credit for the dependents may be claimed by either husband or wife, but it cannot be divided. ${ }^{74}$

\section{PROPOSED SOLUTIONS}

Reversal of Poe v. Seaborn.-In the search for a way to take away the tax advantages of the residents of the community property states and of the residents of the other states who derive income from community property two avenues appear open, one, the judicial, the other, the legislative. To the first the proponents of community property have a ready answer-the question was answered by the Supreme Court more than ten years ago in Poe v. Seaborn. ${ }^{75}$ In that case it was held by a unanimous court that community income derived by a husband and wife resident im Washington from the salary of the husband and from community property was taxable one-half to each spouse. The decision is, however, open to two criticisms of major proportions, the first, that it was in direct contradiction with the language, if not the holdings, in two prior cases, United States $v$.

69 U. S. Treas. Reg. 103 (1940) § 19.182-1(b); G. C. M. 9825 , X-2 C. B. 146 ; cf. Black v. Commissioner, supra note 62 .

70 G. C. M. 15530 , XIV-2 C. B. 107.

71I. T. 3304, 1939-2 C. B. 158.

72 I. T. 1624, II-1 C. B. 145.

73 Stewart v. Commissioner (C. C. A. 5th, 1938) 95 F. (2d) 821; O.D. 909, 4 C. D. 254.

74 I. T. 1275, I-1 C. B. 201.

75. Supra note 3; Goodell v. Koch; Hopkins v. Bacon; Bender v. Pfaff; United States v. Malcolm, all supra note 33 . 
Robbins ${ }^{76}$ and Lucas v. Earl, ${ }^{77}$ and the second, that it is out of line with the more recent decision of the Supreme Court in Helvering $v$. Clifford. ${ }^{78}$

The first of these two attacks, based upon the contention that the Court did not follow its own precedents, would not of itself appear sufficiently strong to break down the authority of Poe v. Seaborn. In the Robbins case the decision, taxing a California husband on the entire income of the community where the income was derived from his earnings and income from community property, was based on two grounds, first, that the husband owned all the community property since the wife under California law had only an expectancy and not a vested interest, and second, that even if the wife did have a vested interest the husband's control was sufficient to warrant taxing hin upon the entire income of the community. In Lucas $v$. Earl the Supreme Court held that the entire salary of a California husband was taxable to hini alone, despite an agreement between the spouses that any property acquired by either should be held as joint tenants. In Poe v. Seaborn the Court found that its first ground of decision controlled in the Robbins case, and dismissed the factor of control by likening the husband's powers over community property to those of an agent. Lucas v. Earl was likewise held not controlling for the reason that "The very assignment iro that case was bottomed on the fact that the earnings would be the husband's property, else there would have been nothing on which it could operate. . . . here, by law, the earnings are never the property of the husband, but that of the community."79

Poe v. Seaborn is susceptible of explanation either on the ground that although Congress could have taxed the entire community inconie to the husband it had not, or that to do so would constitute the taxation of one person on the property of another, a violation of the due process clause of the Fifth Amendment. If the second reason is unsound, then the problem is merely one of statutory construction and the logical solution would appear to be a judicial one, by a reversal of Poe v. Seaborn in the Supreme Court. If that course is not open, or is for other reasons undesirable, then resort must be had

76 Supra note 14.

77 Supra note 29. See 1 Padx, op. cit. supra note 16, at 62. A lucid discussion of these cases appears in MAGIII, TAXABLE INCOME (1936) 268-274.

78 Supra note 48. See Altman, Community Property in Peril (1941) 19 TAxas 262; Lowndes, Community Income and Alimony (1942) 20 TAXEs 3.

79 Poe v. Seaborn, supra note 3 , at 117. 
to legislation which, in turn, must be tested by the due process clause.

A forceful argument can be made to the effect that Poe v. Seaborn can no longer stand in view of the decision of the Supreme Court in Helvering v. Clifford. ${ }^{80}$ In the Clifford case, despite the existence of specific provisions in the statute relating to revocable trusts, ${ }^{81}$ the grantor-trustee of a five-year term trust set up for the benefit of his wife was held taxable on the trust income under the general definition of gross income contained in section 22(a) of the taxing act. $^{82}$ The holding carries out in unprecedented degree ${ }^{83}$ earlier pronouncements that the section containing the general definition of gross income shows the intent of Congress to "... use its power to the full extent . . ." by ". . imposing a tax upon pretty much every sort of income subject to the federal power." ${ }^{85}$ The powers of the husband over community imconie appear fully as great, if not greater than those of the husband in the Clifford case, ${ }^{86}$ and in each case the husband and wife relationship exists. A difference does appear, however, between the duration of the trust in the Clifford case, which was to end in five years or on the earlier death of the husband or wife, and the conimunity property relationship, which would end only with the dissolution of the marriage or by agreement. The reliance upon property-law concepts evidenced in the opinion in Poe v. Seaborn has given way almost completely ${ }^{87}$ to a search for economic control ${ }^{85}$ and benefit ${ }^{58}$ or satisfaction. ${ }^{.0}$ Property law concepts of vesting are no longer the criteria of taxability ${ }_{.}^{91}$ Stare decisis is of little avail. ${ }^{02}$

It seems likely that had Poe v. Seaborn not yet been decided the question presented in that case would now be decided the other way. ${ }^{93}$

So Supra note 48.

S1 Revenue Act of 1934, 48 STAT. (1934) 68, 26 U.S.C. (1940) §§ 166, 167.

82 Ibid.

83 Cf. Burnet v. Wells, stupra note 48 , decided under the predecessor of the present section 167.

84 Douglas v. Willcuts (1935) 296 U. S. 1, 9; see also Irwin v. Gavil (1925) 268 U. S. 161; United States v. Safety Car Heating Co. (1936) 297 U. S. 88, 93 ; Helvering v. Midland Ins. Co. (1937) 300 U. S. 216, 223.

S5 Helvering v. Stockholms etc. Bank (1934) 293 U. S. 84, 89.

${ }^{86}$ See Altunan, op. cit. supra note 78, at 264-265.

87 But cf. I. R. C. $\$ 811($ a).

88 Corliss v. Bowers (1930) 281 U. S. 376; Helvering v. Clifford, supra note 48.

80 Burnet v. Wells, supra note 48.

90 Helvering v. Horst; Helvering v. Eubank; Harrison v.Schaffner, all supra note 32.

01 Helvering v. Hallock (1940) 309 U. S. 106.

02 Ibid. at 119. Cf. the dissenting opinion of Mr. Justice Roberts, ibid. at 123.

08 See 1 PAUL, op. cit. supra note 16, at 62; Altinan, op. cit. supra note 78, at 264. 
The fact that the seven judges who heard the case were unanimous in their decision, however, is a matter not lightly to be dismissed. A problem would arise as to past years, ${ }^{94}$ although taxpayers could hardly claim that they entered matrimony in reliance upon the incidental tax benefits arising therefrom. A more serious difficulty lies in the fact that a reversal of Poe v. Seaborn might not effect the most desirable result, since it would result in taxing the wife's earnings to the husband, rather than to the earner, and yet would permit but one earned income credit. In both of these respects the residents of community property states would be placed at a disadvantage as compared with the residents of the other states. It would appear, therefore, that while the advantages of community property might be removed by resort to the judicial process; a better solution would be achieved through legislative means.

The proposals for the solution by legislative means of the community property problem with respect to the income tax may be grouped into three general categories: (1) mandatory joint returns, either with or without special relief provisions for earned income; (2) the taxation of community income to the spouse, having management and control of the income, either with or without a special provision to tax earned mcome to the earner; and (3) the equal division for income tax purposes by all spouses of their combined incomes. All three types of proposal contain a common constitutional problem, namely, whether the income tax may be computed upon the basis of the family as a unit.

Mandatory Joint Returns.-Proposals for mandatory joint returns were first made by the Treasury in connection with the Revenue Act of 1934. On December 16, 1933, Mr. Roswell Magill, representing the Treasury before the Committee on Ways and Means, in the public hearings on proposed revenue revision legislation submitted a statement which included a recommendation that "... the committee consider whether a husband and wife living together should not be required to file a single joint return, each to pay the tax attributable to his share of the income", adding that "Such a provision has long been in force in other countries." 05 On January 25, 1934, the Ways and Means Committee, after a motion of Mr. Hill

94 Similar questions have arisen before in connection with Helvering v. Hallock, supra note 91, and Helvering v. Clifford, supra note 48.

85 HEARINGS, REVENUE REVISION OF 1934, loc. cit. supra note 6. 
(of Washington) that the Committee take no action in the pending bill relative to commumity property income had been rejected, 10 ayes to 11 noes, adopted a motion of Mr. Lewis (of Maryland) that a proposal for joint returns be inserted in the bill, 15 ayes to 7 noes. On January 26th a motion of Mr. Shallenberger (of Nebraska) to reconsider the vote on joint returns was carried, 18 ayes to 5 noes, as was a motion of Mr. Lewis to adopt the "Parker Proposal No. 1" (prepared by the Staff of the Joint Committee on Internal Revenue Taxation) for the taxation of the income of a marital community to the spouse having the management and control of the community property, 14 ayes to 10 noes. On January 31st, Mr. McCormack's (of Massachusetts) motion that the Committee reconsider this latter proposal was carried, 15 ayes to 9 noes, and Mr. Sanders' (of Texas) motion that the Parker Proposal No. 1 be not included in the revenue bill was carried, 13 ayes to 12 noes...$^{96}$

In the fall of 1937 the Treasury again had under consideration a proposal for joint returns of husband and wife, but no action was taken by Congress, although Undersecretary Magill, in his testinony before the Committee on Tax Evasion and Avoidance, pointed out,

"... the problem of taxing the incomes of spouses has a broader aspect than that of eliminating the discrimination in favor of husbands and wives living together in community-property States. Since spouses living together in nonconımunity-property States nıay file separate returns, there is a strong incentive for them to arrange their property holdings in such a way as to realize the greatest possible tax advantage through a division of inconie or an allocation of losses." $" 97$

A provision for mandatory joint income tax returns of husbands and wives was made in the Revenue Act of 1941, as reported by the Committee on Ways and Means to the House of Representatives, ${ }^{08}$ requiring that a husband and wife living together at any time during their "joint taxable year" should report their incone in a single return niade by then jointly, and that the tax should be computed on their aggregate imconie. Either spouse inight elect to have the liability for the tax upon the aggregate income apportioned between

98 Supplemiental and Dissenting Report of Mr. David S. Lewis to Accompany H. R. 7835, H. R. Rep. No. 704, pt. 2, 73d Cong. 2d Sess. (1934) Ser. No. 9775, at 9-10. 97 Hearings Before the Joint Commititee on Tax Evasion and Avomance, loc. cit. supra note 6 .

98 H. R. REP. No. 1040, op. cit. supra note 6 , § 111. 
them in a ratio which a tax computed upon the separate income of each bore to the sum of such taxes computed upon their separate incomes. Any taxable year in which a husband and wife lived together was to constitute a joint taxable year, except for the year in which the marriage occurred, or, where spouses had not previously established a joint taxable year, the year in which a husband and wife previously separated were reconciled.

On July 24, 1941, the bill was introduced in the House, referred to the Committee on Ways and Means, and submitted to the Committee of the Whole House on the State of the Union. On July 31, 1941, the President sent to Chairman Doughton of the Ways and Means Committee a letter enclosing a copy of a clarifying letter from Secretary Morgenthau and stating that ". . . the Treasury Department does not approve of mandatory joint tax returns except on the condition of granting substantial relief to earned income of the husband and wife. In this I heartily concur. But the committee draft leaves out the proviso altogether."

Chairman Doughton's reply to the President stated that ". . . the committee was unable to see any logic in favoring a family in which both spouses earned the income as against a family where one spouse earned the entire amount for the support of the family."100 The bill actually did give some preferential treatment to earned income since it provided that the net income of each spouse up to and including $\$ 3,000$ was in every case to be considered earned income, and in the case of each spouse the compensation for services actually rendered should be considered as earned income to the extent of $\$ 14,000$. The earned net income of each spouse was to be added together and 10 percent of such earned net income, ${ }^{101}$ was allowable as a credit for the purpose of the normal tax. On August 4, 1941, a separate vote was taken in the House with respect to the mandatory joint returns provision of the bill ${ }^{102}$ and, by a vote of 242 to 160,30 members of the House not voting, the section was stricken from the bill.

Secretary Morgenthau, in his testimony with respect to the bill before the Senate Finance Committee, again pointed out that appropriate relief should be granted where both husband and wife work

90 (Aug. 4, 1941) 87 CoNG. Rec. A-4004.

100 Ibid. at A-4005.

101 The Committee Report, H. R. REP. No. 1040, op. cit. supra note 6, at 10, 39, contained an added qualification, "... but not in excess of 10 percent of the aggregate net income."

$102 \$ 111$. 
outside the home. ${ }^{103}$ Such a provision would tend to alleviate hardships which might result in cases where it is necessary for both spouses to work outside the home. In favor of such relief is the fact that the British mcome tax law makes such a provision in cases where a married woman earns income by her own personal labor, and her husband also earns income unconnected with his wife's business or employment, provided the joint income of husband and wife does not exceed fifty pounds. ${ }^{104}$ The desired result might be achieved by a credit to relieve earned income of the higher surtax rate applicable to the combined incomes of the spouses. Arguments for relief might also be made where a married woman who has inherited property derives income therefrom. It is possible that a compromise might be reached by imposing under joint returns a separate and slightly lower rate of tax. This would, however, necessitate two rate schedules for individuals.

A number of further changes in the 1941 Ways and Means Committee proposal for mandatory joint returns should be considered. The basis provisions of the Internal Revenue Code ${ }^{105}$ might be amended by adding a new subsection to provide that in case of a sale or exchange of property between spouses the basis to the transferee of such property should be the same as it would be in the hands of the transferor, increased in the amount of gain or decreased in the amount of loss recoguized to the transferor upon such transfer under the law applicable to the year in which the transfer was made.

It would also seem better to give the spouses at least a semblance of choice as to whether they would file joint returns. The 1941 proposal would have made joint returns for spouses living together mandatory. In cases where spouses, while held, to be living together under the act, are unwilling to get together for the purpose of filing a return, they might well be permitted to file separate returns, the Treasury making the necessary computation of the aggregate tax liability of both, even though such computation would involve additional work for the Treasury. If the mandatory joint returns proposal is to be adopted, further consideration should be given to the question whether the income of children or dependents living with

103 Heartas Before the Commttree on Finance of the Senate on H. R. 5417, 77th Cong. 1st Sess. (1941) at 3, 7.

104 REPORT OF THE ROYAI COMMISSION ON THE INCOME TAX (1920) pt. III, §VII, at 249,250 .

$105 \S 113$. 
the taxpayer should or should not be included in the joint return. ${ }^{100}$

Aside from the constitutional question, three principal arguments have been advanced at various times against proposals for mandatory jomt returns or the computation of the taxable income of spouses as a unit. These arguments are that the proposal would (1) discriminate against married people living together; (2) infringe upon women's rights and (3) encourage divorce and immorality.

In the House debate on the Revenue Act of 1941 it was repeatedly urged that the provision for mandatory joint returns would constitute a burden or penalty upon marriage. ${ }^{107}$ This argument warrants close examination. A family in which the husband is the sole support clearly would not be discriminated against by mandatory joint returns, since the family would pay no more under that system than such a family now pays. Families in which each spouse has a separate source of income would, of course, be compelled to bear a greater tax burden than they do now, unless the rate of income tax were changed. Spouses in community property states who have been splitting their income for tax purposes would also be compelled to bear a greater tax burden than they do at present. In neither of these instances, however, would the tax burden be any greater than it already is in the family having the same total income but where only one spouse has a source of income. ${ }^{103}$ An instance of discrimination which exists under the present law, but against which no complaint has been voiced, can be found in the fact that a wife who resides in a community property state and has no personal earnings or separate property can be forced to pay an income tax on the ground that one-half of the community income belongs to her. ${ }^{100}$

In the House debate on the 1941 tax bill, considerable emphasis was placed upon the contention that the provision would invade the rights of married women and take away from them privileges which

${ }^{106} \mathrm{~A}$ suggestion that this be done is made in Rudick, The Problem of Personal Income Tax Avoidance (1940) 7 LAW \& Contemp. ProB. 243-264; (July 30,1941) 87 CoNG. Rec. 6618.

107 (Aug. 1, 1941) 87 Cono. Rec. 6768, 6790, 6802; (Aug. 4, 1941) ibid. at 6864, 6868-9, 6871-3, 6880, A-3937, A-3941-2, A-3949, A-3954, A-3996, A-3999.

108 Professor Shoup bas concluded tbat ". . . a compulsory joint return system may easily lead in practice to more inconsistencies than any other, so long as imputed income from labor [the value of a wife's housework] is not to be taxed generally." Shoup, Married Couples Compared with Single Persons Under the Income Tax (1940) 25 Nat. TAX Ass's BuLL. 134.

109 See McKay, op. cit. supra note 12, \$837. Cf. 'Grace v. Carpenter (1941) 42 Cal. App. (2d) 301, 108 P. (2d) 701, to the effect that a husband need not support his wife's mother from his share of community property. 
had been obtained only after generations of struggle. ${ }^{110}$ Any subordination of women that might result from mandatory joint returns would appear, however, to be inore imaginary than real. In fact, although the proposal would appear to confer upon certain women a somewhat greater responsibility as taxpayers than they have borne before, it would treat the married woman in exactly the same manner as the married man for federal tax purposes. In the course of the House debate, it was strenuously urged that although other groups of taxpayers had been given full opportunity for hearings, the women of the country had not been given a chance to voice their objections to the mandatory joint returns proposal. ${ }^{111}$

The public discussion and House debate on the mandatory joint returns provision brought out an unprecedented amount of protest from sources hitherto quite inarticulate in the realm of taxation. The Congressional Record discloses that, among others, various members of the clergy expressed their opinions on the mandatory joint returns proposal with no uncertainty as to their position. These arguments were labelled "emotional claptrap" and "twaddle"112 by some, and were expressly disclaimed on the floor of the House by two members who opposed the mandatory joint returns provision upon other grounds. ${ }^{113}$ The contention that a mandatory joint returns provision would actually result in an increase in the divorce rate is not borne out by the facts with respect to Great Britain, where mandatory joint returns have existed since $1914 . .^{114}$

All the affirmative arguments advanced in favor of inandatory joint returns can be boiled down to the single contention that it would tend to eliminate existing discrimination in the income tax law and thereby establish a uniform system of federal income tax-

110 (July 31, 1941) 87 CoNG. Rec. 6673-6, 6690, 6692; (Aug. 1, 1941) ibid. at 6750, 6781, 6788; (Aug. 4, 1941) ibid. at 6861, 6863, 6864, 6878, 6880, A-3953.

111 Ibid. at $6861,6864,6876$.

1121 bid. at 6618,6750 .

113 Ibid. at $6688,6770$.

114 H. R. Rep. No. 1040, op. cit. supra note 6, at 14. The Report of tHe Royar. CoMmISSION OF THE INCONE TAX, op. cit. supra note 104, at 254, notes in this respect that "It was pointed out that if the allegation is correct that joint assessment is conducive to immorality (an allegation unproved in the course of our inquiry and characterized by one of the women witnesses as being neither reasonable nor probable), the logical, even if not the practicable, remedy is to render liable to joint assessment the income of two unmarried persons living together." As to the likelihood that spouses might obtam divorces and yet continue living together, thereby enjoying the privileges without the tax responsibilities of matrimony, see Rex v. Pratt and Merry, The Tax on Virtue, in HERBER, UNCOMOMON LAW (3d ed. 1937) 397. 
ation. It would eliminate discrimination arising from differences in the property laws of the various states and it would also prevent the unfair operation of the income tax law with respect to a family in which all of the income is received by one spouse, as against families in which each spouse has a separate source of income. Again, it would remove the discrimination which exists against families which are unable to split up their mcome by interspouse transfers, partnerships or trusts. By abolishing such discrimination, mandatory joint returns would tend to place family income tax responsibilities on a basis of ability to pay. ${ }^{115}$ That mandatory joint returns, would be a step toward a uniform system of federal income taxation with respect to individuals has even been noted in some cases by those seeking to defend the community property system. ${ }^{116 .}$

In favor of the mandatory joint returns proposal is the fact that the experience of the British with it has been successful. They have had it in their law since 1914, and although the system has been attacked, it has, nevertheless, after full exammation and debate in the press and in the House of Commons, been retained. ${ }^{117}$

\section{Taxation of Community Income to the Earner or to the Spouse} Having Management and Control.-Proposals for the taxation of community income to the spouse having management and control of the community property were made in connection with the Revenue Acts of 1921, 1924, and 1934. The bill which became the Revenue Act of 1921 , as passed by the House, contained ${ }^{118}$ a provision that "Income received by any community shall be included

115 See H. R. REP. No. 1040, op. cit. supra note 6, at 11-14.

116 (Sept. 3, 1941) 87 Conc. Rec. 7437, 7516; Communit Propertr INCOMr, Hear-

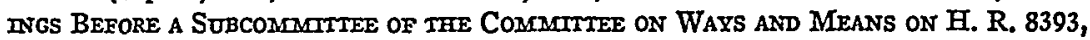
73d Cong. 2d Sess. (1934) at 226; Maggs, Community Property and the Federal Income Tax (1926) 14 CALIF. L. REv. 351, 441, 448; see Individual Views of Senator Connally, SEN. REP. No. 673 oN H. R. 5417, pt. 2, 77th Cong. 1st Sess. (1941) at 4. It is interesting to note, bowever, that in the debate on the floor of the House with respect to the mandatory joint returns provision of the 1941 revenue bill, as reported by the Ways and Means Committee, of the 22 members of the House speaking in favor of the proposal only 2 were from community property states. But of the 40 speaking against the provision, 22 were from community property states. Of the 160 voting in favor of mandatory joint returns only 9 were from community property states. Of these 9 members, 7 were from Oklahoma and 2 from California. (Aug. 4, 1941) 87 CoNG. REc. 6886.

117 See Report of the Royat Comomission on TEE Incone TAX, op. cit. supra note 104, at 248; Income Tax Act 1918, 8 \& 9 GEo. V, c. 40, §8, Gen. Rules 16, 17; Finance Act, $1927,17 \& 18 \mathrm{GEo}$. V, c. 10, $\$ 42(9)$.

118 \$208. 
in the gross income of the spouse having the management and control of the community property."

The Senate Finance Committee proposed to change the final words of the provision to "of such community property" and to add the words " and shall be taxed as the income of such spouse". ${ }^{119}$ An attack on the constitutionality of the proposal was inade on the floor of the Senate and an amendment, proposed by Senator Broussard of Louisiana, to elimmate the provision, was adopted..$^{120}$ The House receded in conference. ${ }^{121}$

In 1924 the so-called "Mellon Plan" provision for taxing community income to the spouse having control of the income was proposed. ${ }^{122}$ Section 213(b) of the Mellon Plan contained a provision that "Income received by any marital community shall be included in the gross income of the spouse having the management and control of the community property, and shall be taxed as the income of such spouse." ${ }^{123}$ The proposal was attacked by taxpayers of the coinmunity property states and was finally abandoned by the Ways and Means Committee. ${ }^{124}$

In 1934 Representative Treadway of Massachusetts introduced a bill, ${ }^{125}$ substantially similar to the 1921 and 1924 proposals. ${ }^{126}$ Extensive hearings were held on the bill before a Subcommittee of the Committee on Ways and Means in May and June 1934, but the Subcommittee, "in view of the legal difficulties involved", made no recommendation with respect to commumity property. ${ }^{127}$ The Treasury at that time recommended joint returns and on January

119 (1921) 61 CoNG. Rec. 5909.

$120 \mathrm{Ibid}$. at $5922,7229$.

121 H. R. REp. No. 486, Amend. 134, op. cit. supra note 4.

122 This plan was set forth by Secretary of the Treasury Mellon in a letter to the Acting Chairman of the Ways and Means Committee on November 10, 1923. See (1923) 67 CONG. REC. 175, 176.

123 Hearings Before Comamttee on Ways and Means, Revenue Reviston 1924, op. cit. supra note 4 , at 349 .

124 Ibid. at $348,349,375,478,482$.

125 H. R. 8396, 73d Cong. 2d Sess.

128 The bill provided, ". . . That for the purpose of determining the income-tax liability of any individual during any taxable year beginming after December 31, 1933, property of a marital community shall be considered as the property of, and income of a marital community shall be considered as the income of, the spouse who has the management and control thereof under the law of the jurisdiction in which the marital community exists, and such spouse shall alone be entitled to the deductions and credits allowed under the internal-revenue laws which are properly allocable to such property or income."

127 Pretuminary Report of a Subcomamtree etc., op. cit. sispro note 4. 
25, 1934, the Subcommittee adopted the Treasury proposal for joint returns. On the next day, however, the Committee reconsidered its vote and adopted instead the so-called "Parker Proposal", worded in almost exactly the same fashion as section 208 of the Revenue Bill of $1921 .^{128}$ Five days later the Committee reconsidered this action and dropped this proposal also. ${ }^{120}$

A plan for taxing community income was included in the Revenue Act of 1941 , as reported by the Senate Finance Committee. ${ }^{130}$ The proposal contained two principal refinements upon the earlier proposals for the taxation of community imcome. The first was the inclusion of a separate provision to tax income earned by each spouse (whether or not treated as community property under the state law) to the earner thereof. It thereby avoids a criticisin that to compute the tax upon the wife's separate earned income by adding it to the husband's earned income and the incone fronl community property over which the husband has inanagement and control would be unfair to the wife. The proposal finds substantial support against arguments of its unconstitutionality in Lucas v. Earl, ${ }^{181}$ wherein Justice Holmes, speaking for the Court, noted that "There is no doubt that the statute could tax salaries to those who earned them ...."182 The second refinement of the 1941 Finance Committee proposal would have excluded from taxation to the spouse having management and control of the property of the marital community, income derived from "such property as constitutes either income derived from the separate property of either spouse or property acquired therewith." This provision was deened necessary to avoid inequities between different community property states, since in Texas, Louisiana and Idaho income derived from the separate property of each spouse or property acquired therewith is community property..$^{123}$

The Finance Committee proposal contained a troublesome ambiguity in that it referred only to income from two sources, from earnings and from property. In some cases there is a serious practical difficnlty of determining what is earned income and what is income

128 "Income received by any marital community shall be included" in the gross income of the spouse having the management and control of the community property."

129 Supplementat and Dissenting Report of Mr. David S. Lewts, op. cil. supro note 96 .

180 SEN. REP. No. 673, op. cit. supra note 4, \$ 119.

131 Supra note 29.

132 Ibid. at 114.

193 See SEN. REP. No. 673 , op. cil. supra note 4 , at 36 . 
from property, where the income arises from a combination of personal services and property investment. ${ }^{134}$ There are, moreover, forms of taxable mcome which cannot readily be termed either earned income or income from property, for example, incoine which arises upon the recovery of a debt previously charged off as worthless, and income resulting from the forgiveness by a creditor of an indebtedness of the taxpayer. It would appear desirable, therefore, to tax all community income to the husband, except that earned income of the wife or income derived from her separate property or from property acquired with her earnings should be taxed to her. Another possibility would be to tax income from community property to the spouse having management and control, unless it be shown by the spouses that the property from which the income was derived was acquired through the other spouse and that it was not acquired from the spouse having management and control, for less than an adequate and full consideration in money or inoney's worth by the other spouse, with a pro rata apportionment where less than an adequate and full consideration was paid. ${ }^{135}$ Such a proposal would derive support from the method of taxing joint interests in property under the federal estate tax. ${ }^{136}$ It would also appear desirable to extend the provision to community income derived under the law of a foreign country or territory or possession of the United States, as well as under the laws of the states.

The principal arguments advanced against the taxation of comnuunity income to one spouse, stated briefly, are as follows: (1) that the community-property marital partnership should not be taxed as an entity when other partnerships are not so taxed; (2) that the spouse having management and control of community income is merely an agent or trustee; (3) that spouses in non-community property states can achieve division of income by making gifts to each other; (4) that spouses in non-community property states can split their income by setting up joint tenancies, tenancies in common, and tenancies by the entirety; (5) that the proposal, with respect to certain states, violates the Treaty of Guadalupe Hidalgo; (6) that the

134 See (Sept. 5, 1941) 87 Cong. Rec. 7518.

135 This possibility is suggested by a provision of the Canadian income tax law to the effect that where one spouse transfers property to the other the income derived from such property or from property substituted therefor is taxed to the transferor as if the transfer had not been made. CaNADA REv. STAT. (1927) c. 97, \& 32(2); see Reiling; Taxing the Income of the Husband and Wife (1935) 13 TAX MAG. 198, 202.

${ }^{188}$ I. R. C. $\S 811(c)$. 
provision would cause an exodus from the community property states; and (7) that the community property states might avoid the provision by dividing management and control between the spouses.

Residents of the community property states have contended that the community property relationship is merely a marital partnership and that there is no more reason for taxing such partnership as an entity than there is for taxing other partnerships as entities. ${ }^{137}$ They assert that the husband is merely a managing partner and that there is no more reason for taxing the income of the community to him alone than there is for taxing the entire firm profits to the manager of an ordinary partnership. Senator Overton made the argument more than vocal by imtroducing an amendment to the Revenue Bill of $1941,{ }^{138}$ providing that the net income of a partnership should be considered as the income of the inanaging partner. The proponents of community property point out that in many states husbands and wives can form partnerships and that in some cases they have been permitted to do it even for the purpose of avoiding taxes. ${ }^{130}$ Today, however, partnerships between husbands and wives are closely scrutinized to determme whether they are being used for the purpose of tax avoidance, and unless each spouse contributes capital, labor or services, no partnership is held to exist. ${ }^{140}$

While the community property relationship is quite analogous to a partnership, the courts have pointed out on numerous occasions that the former is not a partnership and that the rules of partnership do not apply to it. ${ }^{141}$ There are several differences between the two relationships: (1) Unlike the husband and wife in community property states, members of a partnership are generally dealing with each other at arms length. Consequently, the possibilities for tax evasion and avoidance are not entirely the same in both situations. (2) In an ordinary partnership, the contributions of the partners to the firm largely determine the benefits which they are to derive from the partnership efforts. In the case of community property, however, no re-

137 (Sept. 3, 1941) 87 Cong. Rec. 7433, 7434; Individual Views of Senator Connally, op. cit. supra note 116 , at 2 . $^{-}$

138 H. R. 5417, 77th Cong. 1st Sess. (1941) §§120, 181, 182.

130 See B. M. Phelps (1928) 13 B.T.A. 1248; Comaruniry Property Inconre, Fearings, op. cit. supra note 116, at 179; Reiling, op. cit. supra note 135, at 237; Note (1932) 42 YaLE L. J. 265.

140 Robert S. Eaton, supra note 66; (Sept. 3, 1941) 87 Cona. REc. 7429.

141 See Beals v. Fontenot (C. C.A.5th, 1940) 111 F. (2d) 956, 959; Frierson v. Frierson (1927) 164 La. 687, 114 So. 594; Mackenrath v. Pelke (1931) 171 La. 842, 132 So. 365. 
gard is paid to the amounts contributed by the particular spouses, or to their service or business fidelity. ${ }^{142}$ (3) In the case of an ordinary partnership, the creditors of the partnership may assert their rights against the separate property of all of the partners, but the creditors of a husband and wife in community property states are quite limited in their ability to assert their rights against the wife's separate property. ${ }^{143}$ (4) The rights which an ordinary partner has to demand an accounting at any time do not generally exist in the case of commumity property..$^{144}$

It has been asserted in defense of the division of community income for federal income tax purposes that there is no more reason for taxing the community income to the spouse having management and control than there is for including in the individual incone of an agent or trustee the income of his principal or beneficiary. ${ }^{145}$ It is true that the spouse having management and control of community income has been compared at times to an agent or trustee, ${ }^{146}$ but it is clear froin an exammation of the nature of community property that the spouse having managenient and control thereof does have powers considerably in excess of those of an agent or trustee. In fact, such spouse, being the husband in alnost every case, may generally do whatever he wishes with the property, except where such action will defraud his wife.

The proponents of community property point out in their defense that spouses in non-community property states can achieve division of income by making gifts to each other. ${ }^{147}$ In partial answer it should first be noted that spouses in non-community property states cannot assign earnings to each other in such a way as to enable the assignor to escape incoine tax thereon. ${ }^{148}$ In community property states, however, earned income of the spouse is divided equally between the husband and wife for tax purposes. Where inter-spouse gifts are made

142 Holyoke v. Jackson (1882) 3 Wash. Ter. 255, 3 Pac. 841; see (1920) 32 Op. ATI'Y GEN. 303.

133 Cononunity Property Incone, Hearings, op. cit. supra note 116, at 322, 325; (Sept. 3, 1941) 87 CoNG. Rec. 7429.

14 Ibid.

145 Comarunity Property Income, Hearings, op. cit. supra note 116, at 199.

146 See Warburton v. White (1900) 176 U. S. 484, 497; Arnett v. Reade, supra note 12.

147 (Sept.5, 1941) 87 Coxo. Rzc. 7518; Smith, The Community Property Bungle (1929) 7 TAX MAG. 63, 67.

143 Lucas v. Earl, supra note 29; Helvering v. Eubank, supra note 32. Cf. Helvering จ. Horst; Harrison v. Schaffiner, both supre note 32. 
by the use of term trusts or revocable trusts the trusts may be disregarded for tax purposes. ${ }^{140}$ Moreover, it should be pointed out that where transfers between spouses are for less than an adequate and full consideration in money or money's worth, they are subject to gift tax, unless the gifts to any one donee amount to less than $\$ 4,000$ a year and unless the total gifts in excess of such amount total less than $\$ 40,000$ during the lifetime of the donor. ${ }^{150}$

It has also been noted that spouses in non-community property states can split their income by setting up joint tenancies, tenancies in common, and tenancies by the entirety. ${ }^{151}$ In Maryland, tenancies by the entirety may be created even in personal property. ${ }^{152}$ Joint tenants and tenants in common are each taxable on one-half of the profits. ${ }^{153}$ Spouses in non-coinmunity property states may also achieve a division of income from property by conveying an undivided half interest to the other spouse. ${ }^{154}$ But in mitigation of this argument, it should be noted that such transfers may result in the imposition of gift tax. . $^{155}$

Representatives of the taxpayers in California have often asserted that to tax income from community property to one of the spouses alone would violate the Treaty of Guadalupe-Hidalgo, entered into by the United States with Mexico on February 2, 1848, since under the terms of that treaty Californians who were Mexican citizens at the time of the transfer of California to the United States were to have the same property rights which they had previously held under the rule of Mexico. ${ }^{15 B}$ The argument possesses no validity, however, since a taxing act, being a statute enacted by Congress, is of equal dignity with a treaty and if later in time of enactment takes precedence over the treaty. ${ }^{157}$ Moreover, until California changed its law by statute in 1927, the wife under California law had merely an

149 Cf. Helvering v. Clifford, supra note 48; I. R. C. $\$ \S 22$ (a), 166, 167.

150 Ibid. $\S \S 1000,1003-1005$. But the gift tax paid may later become a credit against estate tax. Ibid. $\$ 813(\mathrm{a})$.

151 See Reiling, op. cit. supra note 135, at 201.

152 George E. Saulsbury (1933) 27 B. T. A. 744.

153 Commissioner v. Hart, sitpra note 49.

154 McKee v. Alexander (W.D. Okla. 1931) 48 F. (2d) 838; MAGIL, op. cit. supra note 77, at 274; Surrey, Assignments of Income and Related Devices: Choice of the Taxable Person (1933) 33 Cor. L. Rev. 791, 792, n. 4a, 815.

155 U. S. Treas. Reg. 79 (1936) art. 2.

156 Comomonity Property Income, Hearings, op. cit. supra note 116, at 325; Hearings Before the Joint Comanttee on Tax Evasion and Avoidance, stipra note 6, at 18,315 .

- 157 Rainey v. United States (1914) 232 U. S. 310; 11 AMr. JUR. $§ 43$. 
expectancy and the entire community income was taxable to the husband. ${ }^{168}$

The proponents of commumity property also assert that a couple living in a community property state and deriving income from community property therein might move to a non-community property state, where the income upon receipt would be the separate property of the two spouses, one-half each, ${ }^{159}$ and the income resulting from the investment of that property would be the separate income of the spouses. Thus the spouses could, by moving to the non-community property state, reduce their income taxes. ${ }^{160}$ This contention derives support from the fact that it appears that most states would hold that income derived by residents of a non-community property state from real property situated in a community property state constitutes community income of the spouses. ${ }^{161}$ The general rule that the status of property when acquired as separate or community property continues $^{162}$ would not apply to the non-community property state. If the inconie derived by spouses in a community property state were invested by them in a non-community property state, such investment would be the separate property of the spouses or property held as tenants in common, one-half belonging to each, and the income therefrom would be taxable one-half to each spouse. The fear of an exodus from community property states may have its source in the knowledge that an exodus from some non-community property states has already taken place in the case of spouses desiring to benefit from the federal income tax advantages available to the residents of cominunity property states. Oklahoma's adoption of the community property systein was at least in part motivated by the desire of that state to prevent the removal of its residents to the neighboring community property state of Texas. ${ }^{163}$

158 United States v. Robbins, supra note 14.

150 See Depas v. Mayo (1848) 11 Mo. 314, 49 Am. Dec. 88.

160 (Sept. 3, 1941) 87 CoNG. REc. 7436; (Sept. 5, 1941) ibid. at 7518; Individual Views of Senator Connally, op. cit. supra note 116; Comanountry Propertr Income, HEARINGs, op. cit. supra note 116, at 228.

161 Cf. Hanınonds v. Commissioner, supra note 61; Black v. Commissioner, supra note 62 .

1621 MONTGOMERY, op. cit. supre note 50, at 813.

163 See Daggett, The Oklahoma Community Property Act, a Comparative Study (1941) 2 LA. L. REv. 575-576. It is interesting to note in this connection that Representative Disney of Oklahoma was outstanding in his support of the nuandatory joint returns provision in H. R. 5417, the Revenue Bill of 1941, as reported by the Ways and Means Committee. (July 31, 1941) 87 Cong. Rec. 6688-9, 6691; (Aug. 1, 1941) ibid. at 
It has been suggested that the community property states might avoid the provision by dividing management and control between the spouses by statute. ${ }^{104}$ Even without such statutory measures, considerable doubt might arise in the case of community income in New Mexico where, in certain cases, the wife becomes the head of the community and has management and control of the community property. ${ }^{165}$ It seems that this latter situation might, however, be resolved by those charged with administration of the federal income tax law and, in the event of wholesale statutory revision by community property states, the federal income tax law itself could be amended to prevent avoidance, by taxing the husband.

Three principal arguments appear in favor of the proposal to tax community income to the husband, except for the wife's earned income and income derived from her separate property: (1) that it would remove discrimination; (2) that the spouse having management and control has substantial powers which warrant the imposition upon him of the tax; and (3) that taxes with respect to community property should be enforced against the husband alone, since they are a community obligation. It is evident that the residents of community property states are in a favored position with respect to the federal income tax. It has been pointed out on countless occasions that due to the graduated rates of surtax, a married man earning a salary of $\$ 10,000$ in a non-community property state will pay a considerably higher income tax than will a married man similarly situated in a community property state. The discrimination is less apparent with respect to income from property, since it is possible in noncommunity property states for some taxpayers to lessen their income tax liability by transferring mcome-producing property from one spouse to another, either directly or by means of trusts, but subject to the gift tax. The proposal to tax community income to the earner or to the spouse having management and control of property from which community income is derived would not, therefore, completely remedy the discrimination existing with respect to income from property. In this respect the proposal would be less effective than mandatory joint returns. The first portion of the proposal, however, that

6750; (Aug. 4, 1941) ibid. at 6870-1, 6886. Moreover, all of the Oklahoma members of the House voting on the joint returns provision supported the provision. One Oklahoma member failed to vote. (July 31, 1941) ibid. at 6886.

164 Community Property Income, Hearings, op. cit. supra note 116, at 228. 165 (Sept. 5, 1941) 87 CoNG. REc. 7518. 
earned incoine be taxed to the earner, regardless of whether it constitutes community income or not, would, as to such income, cure the discrimination which exists in favor of residents of community property states and against those in other states.

The spouse having management and control of community property has substantial powers which warrant the imposition upon him of the federal income tax with respect to the income therefrom. In United States v. Robbins, ${ }^{166}$ which held that a California husband was taxable on the entire community income since his wife had a mere expectancy under state law, Justice Holnes noted that "Even if we are wrong as to the law of California and assume that the wife had an interest in the community income that Congress could tax if it so minded, it does not follow that Congress could not tax the husband for the whole." 187 This conclusion is supported by the stateinent of Mr. Justice Cardozo in Burnet v. Wells, that the government in casting about for proper subjects of taxation "... may tax not only ownership, but any right or privilege that is a constituent of ownership." 168

That taxes with respect to community property should be enforced against the husband alone, since they are community obligations, is supported by the leading authority on the law of commumity property. McKay states that, "A tax on community property is a forn of community debt, and in the absence of statute should be enforced as such. This requires that, like other forms of community obligation, it should be enforced against the husband alone...."169 The same authority further points out that, "The wife is not personally liable for community debts, and should not in the absence of a statute be made liable for a tax on community income." $170 \mathrm{McKay}$ clinches the point as follows:

"The apportionment of the tax is based on the false theory that the wife during marriage owns a share in the community property. ... The ownership is not held in shares; it is an indivisible unity during marriage. This is opposed to a division of the tax, either by agreement, for the agreement is not authorized by law, or by compulsion of the federal authorities or by action brought by the spouses or

166 Supra note 14.

167 Ibid. at 327.

168 Supra note 48 , at 678 .

$169 \mathrm{McKaY}$, op. cit. supra note $12, \S 837$.

170 Ibid. $\$ 840$. 
either of them. The compulsory apportionment is opposed to the law of community as it now stands."171

The above argument would go far to support the overruling, without amendment of the income tax law, of Poe v. Seaborn $n^{172}$ and its companion cases holding that spouses in community property states inay divide equally their commumity income for income tax purposes. It is, consequently, a fortiori a reason for the upholding of a statutory provision taxing the entire community income to the spouse having management or control of the community property.

The Equal Division of Income between Spouses-Miscellaneous Proposals.- - On the day ${ }^{173}$ on which the mandatory joint returns provision of the Revenue Act of 1941 was defeated in the House, Representative Dingell of Michigan introduced a bill "174 "To equalize the tax burdens of husbands and wives in non-community property States with those living in community States" which would have amended section 51 of the Internal Revenue Code, relating to individual returns, by adding at the end thereof a new subsection providing that if a luusband and wife living together during the entire taxable year made separate returns, the income of each might be divided equally between thein. In such cases, each was alone to be entitled to onehalf of the deductions and credits properly allocable to such income. The subsection was to apply only to taxable years beginning after December 31, 1940.

The proposal to permit spouses living together to divide their income equally would carry out in all states the analogy of the marital unit to a partnership. ${ }^{175}$ The plan would carry out in practice the practical effect of the suggestion often made by the advocates of the community property system, that that system be adopted

171 Ibid.

172 Supra note 3.

173 August 4, 1941.

174 H. R. 5488, 77th Cong. 1st Sess. (1940).

175 Suggestions along these lines are made in Maggs, op. cit. supra note 116, at 448; Labovitz, The Community Property System-Its Relation to Income, Estate, and In heritance Taxation (1931) 9 Tax Mag. 286, 332, 340. Professor Maggs has also suggested, as an alternative plan, that husbands in community property states be allowed to report one-half of the community income as their own and the other half as trustees for their wives. This alternative suggestion appears to have no merit at all, since it would merely continue the existing situation in the communtiy property states permitting division of community income for tax purposes. 
everywhere. ${ }^{176}$ Professor Shoup ${ }^{177}$ has taken the position that this system may be the one that promises the most in avoiding inconsistencies. In most states husbands and wives experience no great difficulty in achieving a division of their mcome derived from property and, consequently, the bill permitting husbands and wives to divide their imcome equally between them might well be limited to earned income.

It is obvious that a bill permitting all husbands and wives to divide equally their combined incomes would, without an accompanying increase in surtax rates, result in a considerable loss of revenue. This loss might be recovered by an increase in rates, but such increases would only serve to accentuate the severity of the rates im the case of single persons. The solution for this problem would appear to lie in the direction of two different schedules of rates, one for married persons living together who file separate returns, and the other for all other individual income taxpayers. If, however, a similar plan were adopted under the estate and gift tax laws, sharp increases in the rates of those taxes would also be necessary to avoid a loss of revenue.

Two miscellaneous proposals for the solution of the community property problem deserve statement: (1) A requirement that amounts reported on returns by individual taxpayers be determined without mcrease, diminution, or division because of any right, title, or interest created by or dependent on the marriage relation. (2) The denial of deductions where spouses make separate returns. The first of these two proposals ${ }^{178}$ provides entirely too vague a test to permit of practical application. The second ${ }^{179}$ is inadequate to remedy the problems of discrimination and tax avoidance.

\section{CONSTITUTIONAIITY OF COMPUTING THE TAXABLE INCOME OF A}

FAMIIY AS A UNIT

All of the proposals heretofore discussed involve a common constitutional question, namely, whether Congress may enact a provision for the computation of the taxable income of a family as a

178 See Individual Views of Senator Connally, op. cit. supra note 116, at 2; Altman, Community Property and Joint Returns (1941) 19 TAXes 588, 590.

177 Op. cit. supra note 108 , at 134-5.

178 Altman, op. cit. supro note 176 , at 590 .

179 Suggested in Paul and Havens, Husband and Wife Under the Income Tax (1936) 5 BrookIYN I. REv. 241. 
unit. ${ }^{180}$ Those contending that any such provision would be unconstitutional base their position principally on the argument that the provision would, under the decision of the Supreme Court in Hoeper v. Tax Commission of Wisconsin, ${ }^{181}$ constitute taxation of one person upon the income of another and thus a violation of the due process clause of the Fifth Amendinent. The Hoeper case involved a Wisconsin income tax statute which provided that in computing taxes payable by persons residing together as members of a family, the income of the wife and the income of each child under eighteen years of age should be added to that of the husband or father, or if he were not living, to that of the head of the family and assessed to him. It required that the taxes levied be paid ". . . by such husband or head of the family, but if not paid by him may be enforced against any person whose income is included within the tax computation." The statute further provided that married persons living together as husband and wife might make separate returns or join in a single joint return and that "In either case the tax shall be computed on the combined average taxable income." The exemptions were to be allowed but once and divided equally and "... the amount of tax due shall be paid by each in the proportion that the average income of each bears to the combined average income."

Hoeper sued to recover the tax paid on his and his wife's com. bimed incomes, on the ground that the statute as applied to him violated the Fourteenth Amendment. The Court, speaking through Mr. Justice Roberts held that the statute as so applied was unconstitutional as a denial of due process of law, since it was an attempt "to measure the tax on one person's property or income by reference to the property or income of another", and "That which is not in fact the taxpayer's income cannot be made such by calling it income." ${ }^{182}$ Justice Holmes, in a dissenting opinion worthy of his pen, concurred in by Justices Brandeis and Stone, observed,

"This case cannot be disposed of as an attempt to take one person's property to pay another person's debts. The statutes are the outcome of a thousand years of history. They must be viewed against the background of the earlier rules that husband and wife are one, and that one the husband; and that as the husband took the wife's chattels he was hable for her debts. They form a system with echoes 
of different moments, none of which is entitled to prevail over the other. The emphasis in other sections on separation of interests cannot make us deaf to the assumption, in the sections quoted, of community when two spouses hive together and when usually each would get the benefit of the income of each without inquiry into the source. So far as the Constitution of the United States is concerned, the legislature has power to determine what the consequences of marriage shall be, and as it may provide that the husband shall or shall not have certain rights in his wife's property, and shall or shall not be liable for his wife's debts, it may enact that he shall be hable for taxes on an income that in every probability will make his hife easier and help to pay his bills. Taxation may consider not only command over, but actual enjoyment of, the property taxed." 183

Although the Wisconsm statute provided that "the amount of tax due shall be paid by each in the proportion that the average income of each bears to the combined average income", the majority of the Court apparently disregarded this provision in view of the earlier provision that, "The taxes levied shall be payable by such husband or head of the family, but if not paid by him may be enforced agamst any person whose income is included within the tax computation." The Hoeper case derives some support from Poe v. Seaborn, ${ }^{184}$ but the latter case can be explained on the ground that it involved a question of statutory interpretation, rather than of congressional power.

In evaluating the Hoeper case as a precedent it should be noted that the case involved a state statute which was held to violate the Fourteenth Amendment and that a federal statute of the same kind would have to be tested not by the Fourteenth Amendment but by the Fifth Amendment. That a different result would obtain in the case of a federal statute taxing the income of a family as a unit, is mdicated by the numerous cases in which provisions of the federal income tax law taxing one person upon the income of another have been upheld agamst attack based upon the due process clause of the Fifth Amendment. Instances where the federal income tax law may be said to involve the taxation of one person upon the income of the other can be found in the provisions for taxation of a donee of property upon the donor's basis, upheld by the Supreme Court in Taft v. Bowers, ${ }^{185}$ the requirement under the Revenue Act of 1917 that

183 Ibid. at 219.

184 Supra note 3.

185 (1929) 278 U. S. 470. 
affiliated corporations file consolidated returns, upheld in National Candy Co. v. United States, ${ }^{180}$ and the provision ${ }^{187}$ permitting the Commissioner to allocate gross income or deductions between two or more organizations, trades, or businesses (whether or not incorporated, whether or-not organized in the United States, and whether or not affiliated) owned or controlled directly or indirectly by the same interests, if he determines that such allocation is necessary in order to prevent evasion of taxes or clearly to reflect the income of any such organizations, trades, or businesses, upheld in Asiatic Petroleum Co. v. Commissioner. ${ }^{188}$ In Higgins v. Smith ${ }^{180}$ the Court held that a taxpayer could not deduct a loss arising from his sale of stock to a corporation wholly owned by lim.

The Court has appeared particularly willing to hold that one person may be taxed on the income of another where intra-family transfers are mvolved. In Helvering v. Horst ${ }^{100}$ a taxpayer was held taxable upon the amount of interest paid at maturity on coupons which he had detached from bonds and delivered to his son as a gift during the taxable year, the Court noting that the taxpayer ". . . procured payment of the interest, as a valuable gift to a member of his family." A similar and contemporaneous holding as to renewal commissions, arising fron the writing of insurance contracts and assigned to the taxpayer's wife, appears in Helvering v. Eubank. ${ }^{102}$ In Hormel v. Helvering ${ }^{103}$ the grantor of trusts set up for the benefit of his son was held taxable on the trust income, where the grantor and his wife could control the trustees. Harrison v. Schaffner ${ }^{104}$ is along similar lines, holding taxable to the life beneficiary of a trust amounts assigned by lier and paid by the trustees to herechildren.

Even if it were still accepted as a general principle of constitutional law that one person cannot be taxed upon the income of another, the various proposals suggested for the taxation of the

186 (1929) $67 \mathrm{Ct} . \mathrm{Cl} .74$.

187 I. R. C. $\$ 45$.

188 (C. C. A. 2d, 1935) 79 F. (2d) 234.

180 (1940) 308 U. S. 473.

190 Supra note 32. See Pavenstedt, The Broadened Scope of Section 22(a): The Evolution of the Clifford Doctrine (1941) 51 YaLE L. J. 213, 239; Surrey, The Supreme Court and the Federal Income Tax: Some Implications of the Recent Decisions (1941) 35 Irx. L. REv. 779, 784.

191 Supra note 32, at 117.

102 Supra note 32.

103 (1941) 312 U. S. 552.

194 Supra note 32. 
income of a family as a unit might yet be upheld, since they involve not actual taxation of one person upon the income of another, but merely situations wherein the rate of taxation upon the income of one person is measured in part by reference to the income of another. There is a well recognized difference in constitutional law between the subject of a tax and the measure or rate of tax, and an object which in itself could not be made the subject of a tax has often been held properly included in the measure or rate of tax. In Flint v. Stone Tracy $\mathrm{Co}^{195}$ the Supreme Court held that an excise upon the doing of business in corporate form, although measured in part by income from non-taxable bonds, did not violate the due process clause of the Fifth Amendment. In Greiner v. Lewellyn ${ }^{196}$ a federal estate tax was held not to be invalid, even though part of the value of the taxable estate arose from state bonds which the federal government could not tax directly. In numerous cases it has also been held that state taxes may include in the measure of tax things which would not be directly subject to state taxation themselves. ${ }^{107}$

The question boils down to whether the classification of the family as a taxable unit is reasonable. Congress has broad power of classification for tax purposes. This is evidenced by the fact that the taxation of associations, partnerships, stock companies, and business trusts as corporations has been upheld, despite assertions that this constitutes a denial of due process. In Hecht v. Malley ${ }^{198}$ a special excise imposed by the Revenue Act of 1918 on domestic corporations and based upon the average value of their capital stock, including surplus and undivided profits, was held to extend to socalled "Massachusetts trusts", on the ground that they were "associations" and thus within the definition of the term "corporation". In Burnet $v$. Leininger ${ }^{199}$ the taxation of a husband upon his entire distributive share of a partnership of which he was a member was upheld, although he had agreed with his wife that she should be an equal partner with him in his interest in the firm and should share equally with him the profits and losses. The power of Congress to

195 (1911) 220 U.S. 107.

196 (1922) 258 U. S. 384.

197 United States v. Perkins (1896) 163 U. S. 625 ; Plummer v. Coler (1900) 178 U. S. 115 ; Maxwell v. Bugbee (1919) 250 U. S. 525 ; Great AtI. \& Pac. Tea Co. v. Grosjean (1931) 301 U. S. 412 ; Madden v. Kentucky (1940) 309 U. S. 83; cf. National Life Ins. Co. v. United States (1928) 277 U. S. 508; Missouri v. Gehner (1930) 281 U. S. 313. 198 (1924) 265 U. S. 144.

109 Supra note 31. 
classify income for tax purposes has been more recently reaffirmed in the Supreme Court's holding in United States v. Hudson, ${ }^{200}$ that Congress could impose a special income tax of fifty percent on the profits derived from the transfer of interests in silver bullion and in its decision in Helvering v. Northwest Steel Mills, ${ }^{201}$ that the surtax imposed upon undistributed corporate earnings by the Revenue Act of 1936 was constitutional.

Congress, in its classification of subjects for purposes of taxation, may completely disregard state law. This power is shown in BurkWaggoner Oil Ass'n v. Hopkins, ${ }^{202}$ wherein an unincorporated joint stock association, organized in Texas and considered a partnership under Texas law, was held subject to the income and excess profits taxes imposed by the Revenue Act of 1918, although by the common law of Texas a partnership was not considered to be an entity. Further proof of the power of Congress to disregard state law in imposing federal taxes is evidenced in Burnet v. Harmel, ${ }^{203}$ wherein the income received by a lessor from an oil and gas lease was held to constitute ordinary income, although under Texas law the lease in question would have been construed to be a sale of the oil and gas in place.

The argument that the proposals for the computation of taxable income of families as a unit would constitute an unwarranted disregard of determinations as to legal ownership under state law, with a consequent taxation of one person upon the income of another, this being a violation of the due process clause in the Fifth Amendment, finds refutation in the numerous decisions of the Supreme Court holding that for federal tax purposes the test lies not in legal ownership but in the holding of enough of the incidents of ownership to warrant the imposition of a tax. The Court has repeatedly held in both income and estate tax cases that taxation is not concerned with refinements of title. ${ }^{204}$

That treating married persons living together as a separate class for incoine tax purposes constitutes a reasonable classification finds clear support in Brushaber v. Union Pacific $R . R .{ }^{205}$ wherein the Court upheld the income tax law in the form in which it exists today.

200 (1937) 299 U. S. 498.

201 (1940) 311 U. S. 46.

202 (1925) 269 U. S. 110.

203 (1932) 287 U. S. 103.

204 Corliss v. Bowers, supra note 88; Burnet v. Wells, supra note 48 ; Helvering v. Hallock, supra note 91; PaUi, Selected Studies IN Federal TaXation (2d ser. 1938) 41. 205 (1916) 240 U.S. 1. 
Under the Revenue Act of 1913, married persons living together were entitled to a $\$ 4,000$ exemption, whereas single persons and married persons not living together were each entitled to an exemption of $\$ 3,000$. The statute was upheld despite the argument that there was discrimination against married persons living together which violated the due process clause of the Fifth Amendment. The fact that husbands and wives living together conduct their financial affairs as a umit goes far to justify classification of the family as a unit for tax purposes. ${ }^{206}$ That the family is a unit was expressly recognized by the Supreme Court in Burnet $v$. Wells. ${ }^{207}$ In that case Justice Cardozo, noted that in the use of the trust device, "The solidarity of the family is to make it possible for the taxpayer to surrender title to another and to keep domimion for himself, or if not techmical domimion, at least the substance of enjoyment." ${ }^{208}$ Further recognition of the fact that the family may be treated as a unit for tax purposes appears in Helvering v. Clifford, wherein a trust for five years, the income to be paid to the wife of the settlor-trustee was held ". . . at best a temporary reallocation of income within an intimate family group." 209 The fact that the marital relationship affords greater opportunity for tax avoidance is further substantial reason for classification of spouses as a unit under the income tax law. ${ }^{210}$

The Revenue Act itself contains provisions which evidence a recognition of the family as a umit for tax purposes. Husbands and wives living together are permitted to include the income of each in a single return made by them jointly with the tax computed upon the aggregate income. ${ }^{211}$ In Helvering $v$. Janney ${ }^{212}$ it was held that a husband and wife filing a joimt return could set off the capital losses of one against the capital gains of the other. In Taft $v$. Helvering ${ }^{213}$

206 See 1 Paur, op. cit. supra note 16, at 61.

207 Supra note 48.

208 Ibid. at $67 \%$.

209 Supra note 48, at 335. See also Hormel v. Helvering, supra note 193.

210 Cf. Helvering v. City Bank Co. (1935) 296 U. S. 85, 90, wherein the Court stated that "Congress may adopt a ineasure reasonably calculated to prevent avoidance of a $\operatorname{tax} . .$. . A legislative declaration that a status of the taxpayer's creation shall, in the application of the tax, be deemed the equivalent of another status falling normally within the scope of the taxing power, if reasonably requisite to prevent evasion, does not take property without due process."

211 I. R. C. $\$ 51$.

212 (1940) 311 U. S. 189.

213 (1940) 311 U. S. 195. 
it was held that where a husband and wife filed a joint return they could, in computing their net income, deduct their combined charitable contributions from their aggregate gross income up to fifteen percent of the aggregate net income. Again, in the case of a husband and wife living together, the federal incoine tax, prior to the reduction of the exemptions by the Revenue Act of 1941, granted an exemption of $\$ 2,000$ to a husband and wife living together, although the exemption for a single person was only $\$ 800$. Moreover, since 1934 the income tax law has refused to permit deductions for losses resulting from sales of property between inembers of the same family.:14

In view of the overwhelming authority indicating how the Supreme Court would feel on the question were it presented to that tribunal at the present time, there can be little doubt as to the constitutionality of a statutory provision taxing the income of a family as a unit. Because of the interrelation of the income, estate and gift taxes it would be inadvisable to attempt, without a consideration of all three taxes together, a determination as to whether the method to be adopted by Congress with respect to the income tax treatment of cominumity income should be in the form of mandatory joint returns, a specific provision relating to comınunity income alone, or the extension to all married couples of the privilege of dividing their income equally between them for tax purposes. In fact the chief criticism that might be inade as to all of the legislative proposals in the past is that they overlooked the fact that the income tax problem is nierely one aspect of a larger question, and that what might appear to be an excellent solution with respect to the income tax might well result in even greater dislocation 'and inequity under the estate and gift taxes.

214 Revenue Act of $1934 \$ 24$ (a)(6), 48 STAT. (1934) 691; I. R. C. $\$ 24($ b)(1)(A). 